\title{
ASSESSING BRAZIL'S INFORMATION DIFFUSION POWER: A STRUCTURAL HOLE APPROACH
}

\author{
Henrique Morrone* \\ Adalmir Antônio Marquetti ${ }^{\dagger}$ \\ ANa LÚCIa TATSCH ${ }^{\ddagger}$ \\ RicARDo DATHEIN $\S$
}

\begin{abstract}
The objective of this article is to verify the sectors' capacity to diffuse information and knowledge in the Brazilian economy between 2010 and 2015. The input-output technique is used with contributions in network theory and the Structural hole concept, developed by Burt (1992). The results indicate a relevant capacity to diffuse information and knowledge in the economy. This capacity declined in this period. There is a small decline in the diffusion power of the manufacturing and non-manufacturing sectors between the years 2010 and 2015. Low, medium-low and medium technological activities showed a strong capacity to disseminate information throughout the network.
\end{abstract}

Keywords: information and knowledge diffusion, networks, qualitative input-output.

\section{Resumo}

O objetivo deste artigo é verificar a capacidade dos setores para difundir informações e conhecimento na economia brasileira entre 2010 e 2015. Utiliza-se a técnica de insumo-produto acompanhada das contribuições em teoria das redes e do conceito de Structural hole, desenvolvido por Burt (1992). Os resultados sugerem uma relevante capacidade de difusão de informação e conhecimento na economia. Esta capacidade declinou no período. Há um pequeno declínio no poder de difusão da manufatura e do restante da economia entre os anos de 2010 e 2015. Atividades de baixo, médio-baixo e médio níveis tecnológicos apresentaram uma forte capacidade de disseminação de informações através da rede.

Palavras-chave: difusão de informação e conhecimento, redes, insumoproduto qualitativo.

JEL classification: O1, C1, D57.

DOI: http://dx.doi.org/10.11606/1980-5330/ea 153817

\footnotetext{
* Assistant Professor UFRGS. Universidade Federal do Rio Grande do Sul. Av. João Pessoa, 52, 90040-000, Campus Centro, Porto Alegre, RS, Brasil. E-mail: hmorrone@hotmail.com

† Assistant Professor PUCRS. E-mail: aam@pucrs.br

‡ Assistant Professor UFRGS. E-mail: analuciatatsch@gmail.com

$\S$ Professor UFRGS. E-mail: rdathein@terra.com.br
} 


\section{Introduction}

National innovative capacity and its diffusion are central aspects of the economic development (Schumpeter 1994, Ocampo et al. 2009, García Muñiz et al. 2010). Scant innovation and its sluggish spread preclude output growth.

One way to capture the innovative capacity of a region is through an analysis of its industrial interconnectedness and the variety of produced products (García Muñiz et al. 2010, Hidalgo \& Hausmann 2011, Hidalgo 2015). A dense economic structure (with high complexity of inter-sectoral purchases) is essential to the spread of innovations throughout the economic system, avoiding productivity heterogeneity among sectors and leading to economic development (Syrquin 1988, Rodrik 2010, Mazzucatto 2014). The innovative capacity of a region also relies, at least partially, on the spread of information throughout the productive sectors.

In this context, there is a large body of input-output research that assesses information and knowledge diffusions within the economic system. The pioneer works of Scherer (1982) and Leontief (1986) investigated the diffusion that applies input-output tables. Recent studies such as Wolff (1997), Mohnem (2001) and Dietzenbacher \& Luna (2005) follow similar approaches. These works depend on the sectoral input-output coefficients, concerned mostly with size, number of linkages and propagation length.

Conversely, few studies have analysed the diffusion of information from a perspective based on network theory and the structural hole concept, developed by Burt (1992). Network theory has important applications in mathematics, physics, medicine, biology, sociology, economics, business, among others (Jackson 2008). In economics, it is important for examining the economic structure and detecting clusters (Aroche Reyes 1995, Lahr \& Dietzenbacher 2001). The sector's diffusion power relies on its relative position in a network and the structure of this sector's relations in the economic system (García Muñiz et al. 2010). Looking at the influence that networks' structural features have on the transmission process is key to understanding economic development if it is analysed in conjunction with taxonomies that separate sectors according to their technology levels (García Muñiz et al. 2010). Interindustrial sales allow sectors to incorporate knowledge embodied in inputs and can help to better understand labour productivity growth (Schmookler 1966, Rosenberg 1982, Gonçalves \& Ferreira Neto 2016). This intersectoral transfer of information and technology is a pivotal source of knowledge for the entire economy (Mansfield 1971).

The type of productive ties matter in the diffusion process; even quantitatively weak links may transport valuable information (Granovetter 1974). Burt considers non-redundant ties as crucial to the spread of information. They are exclusive links with other groups that lead to different sectors, giving access to diverse information benefits. Structural holes connect these links. Sectors with high numbers of non-redundant transactions (and structural holes), detain information control and can be a benefit since they can start new links, helping to diffuse information (Hanneman \& Riddle 2005). They are suppliers of varied information, having intermediation power and acting as "bridges" to the propagation of information. Thus, Burt's model measures the sectoral capability for information/knowledge dissemination between (not within) interconnected areas.

In this paper we employed this procedure to investigate the possibilities 
for sectoral information and knowledge diffusions in Brazil in 2010 and 2015. ${ }^{1}$ These two years capture different phases of the last business cycle: the economy was thriving in 2010, while in 2015 it was in a profound recession. The present paper draws heavily on Burt (1992) and García Muñiz et al. (2010)'s contributions. Furthermore, our article explores the capacity of information diffusion of different segments within the economy - separated by technological intensity: low, medium-low, medium, medium-high and high - based on official classification (OECD - Organização para a Cooperação e Desenvolvimento Econômico 2003, 2011, Galindo Rueda \& Verguer 2016). We address five questions: What is the Brazilian capacity to spread information throughout the system? Considering points in two different phases of the last business cycle (years 2010 and 2015), how has the system's capacity to transmit information changed? In terms of the efficiency to spread knowledge, is manufacturing different from the rest of the economy? What are the technological segments (as a group) that diffuse more information? Which productive activities spread more information and knowledge throughout this country's network?

It is important to evaluate the patterns of diffusion of information $/ \mathrm{know}$ ledge because Brazil has changed its productive structure more towards agricultural and service activities. Studying the manufacturing sector is also relevant since it contains many productive links and is considered an innovative activity with power to spread innovations (Ocampo et al. 2009). We used the official Input-output tables for the years 2010 and 2015 as a benchmark in our estimations. ${ }^{2}$ These symmetric tables are highly disaggregated, comprising 62 sectors. Employing disaggregated tables has an advantage since it mitigates aggregation bias in the results (Aroche Reyes 1995, Miller \& Blair 2009). ${ }^{3}$ To our knowledge, there is no meso-economic study of technological diffusion for Brazil, not to mention using network theory and the structural hole approach. Thus, the current paper attempts to fill a gap in the literature.

This article contains three additional sections. In the following section we present the method and data. The results are presented and discussed in section three. Section four concludes.

\section{Methodology and Data}

To explore the information/knowledge diffusion power of a region, we have presented a technique to gauge the sectoral capacity to transmit information. Burt (1992)'s model is the template for our analysis of information diffusion. Next, we introduced the data set. We used the official symmetric I-O tables for the years 2010 and 2015 from the Brazilian Institute of Geography and Statistics (IBGE). ${ }^{4}$

\footnotetext{
${ }^{1}$ We would like to thank the valuable comments of an anonymous referee.

${ }^{2}$ An alternative data set that could be utilized is the world input-output database. Its advantage is to allow international comparisons but it has a cost in terms of using a relatively high aggregated table. We opted to employ the Brazilian database only.

${ }^{3}$ Sectoral aggregation involves adding sectors with different technical coefficients which may cause bias in the results. In this sense, each aggregated sector would be formed by a weighted average of different techniques of production (Aroche Reyes 1995, Miller \& Blair 2009).

${ }^{4}$ The intersectoral transactions matrices are available on demand and can also be found on the IBGE website. Our results were estimated using the network software UCINET VI.
} 


\subsection{Method}

Economic development results from an increase in the size and density of the input-output matrices (Syrquin 1988). It is an unbalanced process in which disequilibrium among sectors and gaps in the productive structure are a common feature of economies, creating opportunities to invest and grow (Hirschman 1959, Burt 1988). As the network grows in size, however, the rate of growth in the flow of diverse information might fall behind. In Burt (1992) words:

"Size is a mixed blessing. Increasing network size without considering diversity can cripple a network in significant ways. What matters is nonredundant contacts. Contacts are redundant to the extent that they lead to the same people (sectors), and so provide the same information benefits".

In this context, detecting non-redundant links in the network is central to assess the capacity to diffuse knowledge in the economy.

A structural hole is defined broadly as a non-redundant (exclusive) relationship between two sectors (García Muñiz et al. 2010). Non-redundant connections determine bridge relationships expressed by structural holes. These links lead to different sectors that give diverse information. A sector's position and its structural relations affect the ease with which information spreads. The gist of Burt's argument was that activities with several structural holes (and non-redundant links) would be strategic, containing potencial to explore and create competitive advantages.

The investigation of structural holes requires computing the network size, and redundant and non-redundant ties. Redundancy is related to cohesion (strong ties) and structural equivalence (sectors that detain similar contacts). It can be estimated as the average degree (number of links, not counting ties toward ego) of the ego alters (not computing ties to the ego) (Borgatti 1997). In network jargon, an ego is an individual focal node and an ego network is a part of a given network formed by the ego and its alters. The latter being the nodes that are connected to the ego. ${ }^{5}$

After we have calculated the redundancy it is possible to estimate the nonredundancy as a residual. In other words, the level of non-redundancy (or effective size) is equal to the network size (number of ties emerging from the ego) minus its level of redundancy. The larger this indicator, the more access to varied information this sector has.

Furthermore, we can normalize by the network size, finding the efficiency index. It shows which proportion of an ego's linkages to its ego network is non-redundant (Hanneman \& Riddle 2005). It presents values between 0 and 1 . Values close to 0 mean that the sector has a substantial level of redundancy in its linkages. Otherwise, values near 1 indicate a high number of non-redundant productive links and high efficiency in the capability to obtain (and explore the benefits of) varied information (García Muñiz et al. 2010). Figure 1 shows two networks that help us to explore the concept of redundancy, non-redundancy and efficiency.

\footnotetext{
${ }^{5}$ Because Burt's original model is somewhat cumbersome, we presented a simpler way to capture non-redundancy introduced by Borgatti (1997). (Burt's original exposition is presented in the appendix.) Borgatti (1997) suggests that redundancy is equal to the ego net density scaled by $\mathrm{n}-1$, where $\mathrm{n}$ stand for the number of nodes. It is possible to assess redundancy using the formula $2 t / n$, where $t$ stands for the number of ties in the network (not considering ties to ego) and $\mathrm{n}$ is the number of nodes (also not including ego) (Borgatti 1997). A structural hole is an
} 
Figure 1: Hypothetical ego network in cases where Sector E (ego) presents redundant (a) and non-redundant (b) connections.

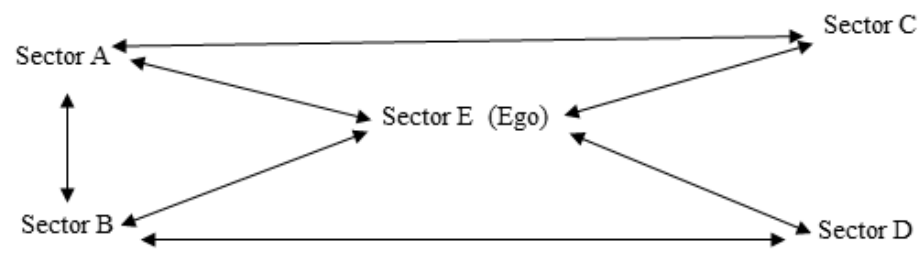

(a) Ego network " $\mathrm{a}$ ". Sector $\mathrm{E}$ is the ego and the remaining sectors denote ego alters.

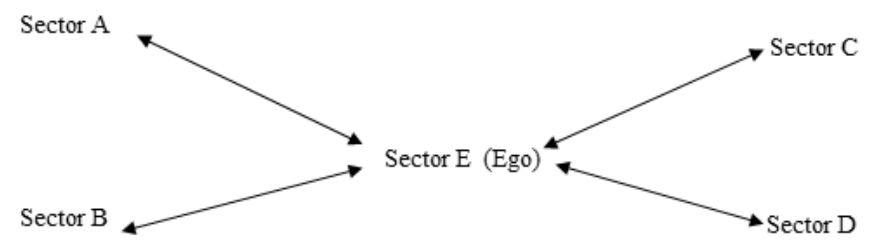

(b) Ego network " $\mathrm{b}$ ". Sector $\mathrm{E}$ is the ego and the remaining sectors denote ego alters.

Source: author's elaboration.

A glance at Figure 1(a), allow us to verify that information flows among all sectors. Each sector knows what the others know (Burt 1992). In this sense, some links could be excluded without reduction in information. It is a typical case of redundancy. In Figure 1(a), sectors A, B, C and D are the ego alters and have degree 2,2,1, and 1 . Their average (and redundancy) equals 1.5. Non-redundancy is simply an ego's connections (4) minus the redundancy level (1.5), having as a result 2.5 non-redundant contacts as its effective size. The efficiency indicator is equal to $0.625(2.5 / 4)$, or 62.50 per cent. Sector E has a secondary role for the transport of information. Conversely, Figure 1 (b) shows a different picture. It reveals the importance of Sector E (ego) in the network. There are no links between the other (alter) sectors, so redundancy is zero and non-redundancy equals 4 . The efficiency index equals $1(4 / 4)$, or 100 per cent. Sector E can control the information and its diffusion and benefit from it. It is a supplier of diverse information, having intermediation power. The larger the number of non-redundant contacts, the richer the information that this sector holds. It is more likely that a sector contains a high level of varied information when this branch is connected to several other sectors with absent interconectedness between themselves (Figure 1b) than is the case in 
Figure 1a. To summarise, sector $\mathrm{E}$ is unimportant to spread information in Figure 1(a) while this sector is pivotal to the flow of information in Figure $1(\mathrm{~b})$.

Therefore, the presented method is fitted to analyze the evolution of the diffusion of ideas and information in Brazil. It can emphasize the role played by each activity of the economy.

\subsection{Data}

The official symmetric input-output tables for the years 2010 and 2015 come from the Brazilian Institute of Geography and Statistics (IBGE). Specifically, we employed Table 3 (supply and demand for domestic production at basic prices) in conjunction with Table 14 (Intersectoral technical coefficients' matrix, D.Bn), both from the official I-O matrix, to estimate the interflow of sectorial transactions. ${ }^{6}$

The matrices originally comprised 67 sectors. The sectoral aggregation follows the classification applied by the Brazilian Statistical Office, CNAE 2.0. Following (Burt 1988, 1992), we excluded government activities in this research, resulting in 62 activities. ${ }^{7}$ We chose both years because there was a methodological change in the System of National Accounts in 2010 which made comparisons with previous years difficult if not impossible.

There are two benefits in using the structural hole approach in these matrices. Firstly, it avoids the loss of information presented in graph theory and other qualitative methods. ${ }^{8}$ Secondly, the method can capture the capacity for each sector to spread knowledge due to its relative position and structural relations in the network. Table 1 exhibits the technological classification for sectors based on official classification (OECD - Organização para a Cooperação e Desenvolvimento Econômico 2011, Galindo Rueda \& Verguer 2016).

\section{Results}

Table 2 displays the results for the sectors' efficiency levels in Brazil for the years 2010 and 2015. Measuring the non-redundant level, allows us to pinpoint the activities that contain higher capability to diffuse and foster information in the economy. It also highlights activities with high efficiency in obtaining (and exploring the benefits of) varied information.

The numbers in Table 2 exhibit the efficiency in assessing varied information in the network. They report on an important capacity of the Brazilian economy to spread information within the system due to the high number of non-redundant sectoral relations.

\footnotetext{
${ }^{6}$ To estimate the sector by sector sectorial transactions matrix from the official I-O table, we can follow two steps. First, it is required to calculate the ratio of each technical coefficient, from Table 14 (D.Bn), to the respective column total. Second, we should multiply the obtained ratios by the column totals from Table 3 (supply and demand for domestic production at basic prices). We thank an anonymous referee for raising this point.

${ }^{7}$ The list of 62 sectors is available in the Appendix. Usually, government activities are excluded from the analysis because their results are imputed in national accounts (Shaik \& Tonak 1994, Assa 2015). For the same reason, the activities of (household) domestic service supplied for families, public education, public health and real estate were also excluded.

${ }^{8}$ Qualitative methods usually transform the I-O table into a Boolean matrix, which contains only zeros and ones. Valuable intersectoral links are set to one, otherwise they are zero. This process necessarily involves the loss of important information. The structural hole approach avoids it since it can be conducted in both I-O and Boolean matrices.
} 
Table 1: Sectoral Classification by technological intensity level.

\begin{tabular}{|c|c|}
\hline Sectors & $\begin{array}{c}\text { Technological } \\
\text { level }\end{array}$ \\
\hline $\begin{array}{l}\text { Agriculture } \\
\text { Livestock } \\
\text { Forestry and fisheries } \\
\text { Electricity, natural gas and other utilities } \\
\text { Water, sewage and waste management } \\
\text { Construction } \\
\text { Wholesale and retail trade, except motor vehicles } \\
\text { Ground (Inland) transportation } \\
\text { Maritime transportation } \\
\text { Air transport } \\
\text { Storage, auxiliary transport and mail activities } \\
\text { Accommodation } \\
\text { Food supply (Feeding) } \\
\text { Television, radio, cinema and sound / image recording / editing activities } \\
\text { Financial intermediation, insurance and supplementary pension plans } \\
\text { Non-Real Estate rentals and intellectual property asset management } \\
\text { Other administrative activities and complementary services } \\
\text { Surveillance, security and research activities } \\
\text { Private education } \\
\text { Private health } \\
\text { Artistic, creative and entertainment activities } \\
\text { Associations and other personal services }\end{array}$ & Low \\
\hline $\begin{array}{l}\text { Extraction of coal and non-metallic minerals } \\
\text { Extraction of oil and gas, including support activities } \\
\text { Extraction of iron ore, including processing and agglomeration } \\
\text { Extraction of non-ferrous metal ores } \\
\text { Slaughter and meat products, including dairy products and fishery products } \\
\text { Manufacture and refining of sugar } \\
\text { Other Food Products } \\
\text { Manufacture of beverages } \\
\text { Manufacture of tobacco products } \\
\text { Manufacture of textiles } \\
\text { Manufacture of wearing apparel } \\
\text { Manufacture of footwear and leather } \\
\text { Manufacture of wood products } \\
\text { Manufacture of pulp, paper and paper products } \\
\text { Printing and reproduction of recordings } \\
\text { Oil refining and coking plants } \\
\text { Manufacture of biofuels } \\
\text { Manufacture of furniture and other products } \\
\text { Print-integrated editing and editing } \\
\text { Telecommunications } \\
\text { Legal, accounting, consulting and corporate headquarters activities } \\
\text { Architectural, engineering, testing / technical analysis and R \& D services } \\
\text { Other professional, scientific and technical activities }\end{array}$ & $\begin{array}{l}\text { Medium- } \\
\text { low }\end{array}$ \\
\hline
\end{tabular}

Source: OECD - Organização para a Cooperação e Desenvolvimento Econômico (2003, 2011), Galindo Rueda \& Verguer (2016) and author's elaboration. 
Table 1: Sectoral Classification by technological intensity level. (continued)

\begin{tabular}{|c|c|}
\hline Sectors & $\begin{array}{c}\text { Technological } \\
\text { level }\end{array}$ \\
\hline $\begin{array}{l}\text { Manufacture of rubber and plastic } \\
\text { Manuf. of non-metallic mineral products } \\
\text { Production of pig iron / ferrous alloys } \\
\text { Metallurgy of non-ferrous metals } \\
\text { Manufacture of metal products } \\
\text { Maintenance, repair and installation of machines }\end{array}$ & Medium \\
\hline $\begin{array}{l}\text { Manufacture of other organic and inorganic chemicals } \\
\text { Manufacture of pesticides, disinfectants } \\
\text { Manufacture of cleaning products, cosmetics } \\
\text { Manufacture of machinery } \\
\text { Manufacture of cars, trucks and buses } \\
\text { Manufacture of parts and accessories } \\
\text { Manufacture of other transport equipment }\end{array}$ & $\begin{array}{l}\text { Medium- } \\
\text { high }\end{array}$ \\
\hline $\begin{array}{l}\text { Manufacture of pharmaceutical } \\
\text { Manufacture of computer, electronic } \\
\text { Manufacture of electrical machinery } \\
\text { Development of systems and other information services }\end{array}$ & High \\
\hline
\end{tabular}

The economy's efficiency, despite being high, declined slightly between 2010 and 2015. Statistical tests reveal that the difference between the averages; it moved from 83.5 percent in 2010 to 82.2 in 2015, was statistically significant. (García Muñiz et al. (2010) found an efficiency level of 73.59 per cent for Spain in 1995). The crisis that hit Brazil recently seems to have had an impact in terms of the capacity of the whole system to diffuse information. ${ }^{9}$ In this vein, meso-economic and qualitative changes took place. In the context of a deep recession, the small decrease in the country's diffusion power suggests the resistance of the system to shocks.

For the years 2010 and 2015, the efficiency of manufacturing was somewhat smaller than the rest of the economy. We found a mean efficiency index of 82.9 per cent for non-manufacturing and 81.6 per cent for manufacturing in 2015. Statistical tests highlight that for both 2010 and 2015 the difference between the means was not significant. ${ }^{10}$ This evidence suggests that in relative terms of its capacity to spread information, a principal role for manu-

\footnotetext{
${ }^{9}$ Although it was difficult, if not impossible, to separate the analysis from the recent economic crisis, we found that our results seem consistent since there is a change in the results for a year with high ouptut growth (2010) and a year of recession (2015). As mentioned, we found using parametric and non-parametric statistical tests that the differences of averages are significant. Both distributions are approximaly normal with t-value -11.19 (p-value lower than 0.0001) and $\mathrm{z}$-score -6.67 (p-value lower than 0.0001). The Mann-Whitney U test, a non-parametric test, indicated that the difference between the means are statistically significant at 1 and $5 \%$. The Sign and Wilcoxon sign rank tests also confirmed this result.

${ }^{10}$ Both distributions are approximatelly normal with $\mathrm{z}$-score -1.73 (p-value is equal to 0.08 ) for the year 2010. For 2015, we found a z-score -1.55 (p-value is equal to 0.12) The Mann-Whitney U test, a non-parametric test, gave the same results in terms of the non significance of the difference of the means at 1 and 5 per cent. Further results are available on demand.
} 
facturing was absent in Brazil. ${ }^{11}$ In this vein, agriculture and service sectors seem equally well suited to spread information in the productive structure.

This result is somewhat puzzling since a vast body of literature points to the centrality of manufacturing in spreading information. It seems that despite the benefits of manufacturing for the economy, information diffusion might not be a justification to promote manufacturing in Brazil. ${ }^{12}$ However, this result might be related to the recent economic crisis and the well-known phenomenum of deindustrialization of the Brazilian economy. There are studies showing the decline of manufacture in this country. ${ }^{13}$

Other studies using different methods stressed the key role played by agriculture and service activities in Brazil. ${ }^{14}$ For instance, Souza (1988) employed the input-output approach and found that agriculture was pivotal to stimulate the economy because of its strong downward and forward productive linkages. VieiraFilho et al. (2013) found that agriculture presented strong productive chains that facilitate the spread of information/knowledge to the rest of the economy. Jacinto \& Pontual (2015), employing an alternative decomposition method, showed that services presented higher labour productivity growth during the 2000s in Brazil when compared to manufacturing. (Kon 2003, 2013) suggested that services can foster output growth since they have important productive linkages, demanding inputs from manufacturing. There is a segment of services, known as knowledge-intensive business services (for example, accounting and legal assistance, advertising and design, arquitecture and design services, etc.), that can induce innovations in manufacturing (Ambrozio \& Melo 2017). Our results complement their analysis showing that not only do agriculture and services contribute to economic expansion, these sectors also have strong power to spread information in Brazil.

Moreover, results reveal that the manufacturing and non-manufacturing capacities to spread information dropped over the period. According to the statistical tests, ${ }^{15}$ both segments had their diffusion capacity diminished.

When comparing the different segments of manufacturing and non-manufactu-ring to the mean of the economy, the following results were obtained. Within manufacturing, important sectors reported higher efficiency levels both in 2010 and 2015. They were: manufacture of beverages (medium-low); manufacture of other organic and inorganic chemicals (medium-high); production of pig iron/ferrous alloys (medium); manufacture and refining of sugar (medium-low-tech.); manufacture of biofuels (medium-low); and oil refining and coking plants (medium-low-tech.). For non-manufacturing, the important activities in terms of diffusion capacity in 2015 were: wholesale and retail trade (low tech.); television, radio, cinema and sound activities (low tech.);

\footnotetext{
${ }^{11}$ This positive spillover effect is not uniform since agriculture comprises many heterogeneous activities.

${ }^{12}$ We thank an anonymous referee for highlighting this point.

${ }^{13}$ We thank an anonymous referee for highlighting this point.

${ }^{14}$ Both sectors are productive and can contribute to economic growth (Dasgupta \& Singh 2005). However, services might be a complement to manufacturing, being subordinate to the manufacturing development. It is an empirical long-term question that is out of the scope of this paper. Kaldor (1968), Baumol (1986), Cohen \& Zysman (1987) and Chang (2014) suggest the existence of this dependence of services in relation to manufacturing.

${ }^{15}$ The $t$-test indicated that the difference between the means for manufacturing in 2010 and 2015 are statistically significant. It rejects the null hypothesis at 5 per cent. We found that the $\mathrm{t}$-value is equals to -7.13 ( $\mathrm{p}$-value lower than 1 per cent). Additional results are available on demand.
} 
agriculture (low); extraction of coal and non-metallic minerals (medium-low); extraction of oil and gas, including support activities (medium-low); maritime transportation (low); air transport (low), and extraction of non-ferrous metal ores (medium-low). In line with Cassiolato \& Vitorino (2011), opportunities are found in sectors related to the environment and infrastructure. In the medium-tech segment, architectural, engineering, testing / technical analysis and R \& D services and other professional, scientific and technical activities presented indexes larger than the mean of the economy. Development of systems and other information services, an activity in the high-tech segment, presented an efficiency index lower than the mean of the economy. This service supports the manufacturing sector and the primary and tertiary sectors. The only activity close to the mean of the economy in this segment was the manufacture of pharmaceutical products.

Regarding economic performance and its componentes with different levels of technology, we found a decline in the efficiency between 2010 and 2015. On average, the low, medium-low and medium tech segments, as groups, displayed the two highest efficiency indexes within the economy. ${ }^{16}$ It captured the process of specialization in Brazil. Most of the opportunities are concentrated in these groups which condition the type of innovation taking place in the economy. High intensity sectors presented the smaller efficiency. It was followed by mid-high-tech activities.

The estimated results therefore, show a strong but decreasing capacity to spread information/knowledge in the network. The low, medium-low and medium-tech activities present strong diffusion power. The opportunities that structural holes create are, in relative terms, concentrated mostly in these clusters. Nonetheless, specialization in these activities has a side effect since they are strongly related to commodities and more cyclically prone than other segments in developing countries (Ocampo et al. 2009). Supporting research in products and processes in the few sectors located in the mid-high segment with efficiency index superior than the economy's mean, is also important to upgrade the national capacity to innovate and the type of innovation taking place.

\section{Concluding Remarks}

This article has applied network theory and the concept of structural hole to detect the number of non-redundant connections in the Brazilian economy in 2010 and 2015. We employed the official I-O tables for both years. Employing this method, we were able to select the activities with higher capacity to diffuse information and knowledge. The spread out of information hinges on sector's position and structural relations in the whole network. In general, the results showed a high potential for the economy to spread information. Comparing results for two different phases of the business cycle, we found that this capacity slightly diminished in this period. At any rate, the system, in terms of its capacity to diffuse information, seems resistant to shocks since Brazil suffered a deep economic and political crisis in 2015.

\footnotetext{
${ }^{16}$ Statistical tests, parametric and nonparametric, indicate that the difference between the averages of low and mid-low tech are not statistically significant at 1 and $5 \%$. That is, low-tech activities on average do not diffuse more information than the mid-low segment. For the other segments, the sample is too small so results should be taken with a grain of salt.
} 
Table 2: Non-redundant contacts for manufacturing in Brazil.

\begin{tabular}{|c|c|c|}
\hline \multirow[b]{2}{*}{ Sectors } & 2010 & 2015 \\
\hline & $\begin{array}{l}\text { Efficiency } \\
\text { index }\end{array}$ & $\begin{array}{l}\text { Efficiency } \\
\text { index }\end{array}$ \\
\hline Agriculture & 0.877 & 0.854 \\
\hline Livestock & 0.872 & 0.857 \\
\hline Forestry and fisheries & 0.881 & 0.866 \\
\hline Electricity, natural gas and other utilities & 0.835 & 0.818 \\
\hline Water, sewage and waste management & 0.825 & 0.814 \\
\hline Construction & 0.840 & 0.826 \\
\hline Wholesale and retail trade, except motor vehicles & 0.880 & 0.883 \\
\hline Ground (Inland) transportation & 0.819 & 0.797 \\
\hline Maritime transportation & 0.861 & 0.850 \\
\hline Air transport & 0.846 & 0.836 \\
\hline Storage, auxiliary transport and mail activities & 0.827 & 0.807 \\
\hline Accommodation & 0.837 & 0.818 \\
\hline Food supply (Feeding) & 0.841 & 0.819 \\
\hline $\begin{array}{l}\text { Television, radio, cinema and sound / image recording / } \\
\text { editing activities }\end{array}$ & 0.873 & 0.871 \\
\hline Financial intermediation, insurance and pension plans & 0.842 & 0.832 \\
\hline $\begin{array}{l}\text { Non-Real Estate rentals and intellectual property } \\
\text { asset management }\end{array}$ & 0.827 & 0.818 \\
\hline $\begin{array}{l}\text { Other administrative activities and } \\
\text { complementary services }\end{array}$ & 0.794 & 0.782 \\
\hline Surveillance, security and research activities & 0.785 & 0.769 \\
\hline Private education & 0.845 & 0.835 \\
\hline Private health & 0.766 & 0.752 \\
\hline Artistic, creative and entertainment activities & 0.860 & 0.851 \\
\hline Associations and other personal services & 0.874 & 0.860 \\
\hline Extraction of coal and non-metallic minerals & 0.850 & 0.853 \\
\hline Extraction of oil and gas, including support activities & 0.858 & 0.850 \\
\hline $\begin{array}{l}\text { Extraction of iron ore, including processing } \\
\text { and agglomeration }\end{array}$ & 0.823 & 0.820 \\
\hline Extraction of non-ferrous metal ores & 0.872 & 0.851 \\
\hline $\begin{array}{l}\text { Slaughter and meat products, dairy products } \\
\text { and fishery products }\end{array}$ & 0.866 & 0.851 \\
\hline Manufacture and refining of sugar & 0.855 & 0.853 \\
\hline Other Food Products & 0.820 & 0.813 \\
\hline Manufacture of beverages & 0.863 & 0.856 \\
\hline Manufacture of tobacco products & 0.830 & 0.824 \\
\hline Manufacture of textiles & 0.870 & 0.861 \\
\hline Manufacture of wearing apparel & 0.831 & 0.803 \\
\hline Manufacture of footwear and leather & 0.806 & 0.784 \\
\hline Manufacture of wood products & 0.830 & 0.814 \\
\hline Manufacture of pulp, paper and paper products & 0.825 & 0.808 \\
\hline Printing and reproduction of recordings & 0.777 & 0.732 \\
\hline Oil refining and coking plants & 0.846 & 0.845 \\
\hline Manufacture of biofuels & 0.856 & 0.849 \\
\hline Manufacture of furniture and other products & 0.834 & 0.821 \\
\hline Print-integrated editing and editing & 0.826 & 0.811 \\
\hline Telecommunications & 0.808 & 0.802 \\
\hline $\begin{array}{l}\text { Legal, accounting, consulting and } \\
\text { corporate headquarters activities }\end{array}$ & 0.819 & 0.809 \\
\hline $\begin{array}{l}\text { Architectural, engineering, testing, technical analysis } \\
\text { and R\&D services }\end{array}$ & 0.854 & 0.849 \\
\hline Other professional, scientific and technical activities & 0.846 & 0.827 \\
\hline
\end{tabular}

Source: author's computations.

Note: The software UCINET VI was employed in the estimations. 
Table 2: Non-redundant contacts for manufacturing in Brazil. (continued)

\begin{tabular}{l|c|c}
\hline \multicolumn{1}{c|}{ Sectors } & $\mathbf{2 0 1 0}$ & $\mathbf{2 0 1 5}$ \\
\cline { 2 - 3 } & $\begin{array}{c}\text { Efficiency } \\
\text { index }\end{array}$ & $\begin{array}{c}\text { Efficiency } \\
\text { index }\end{array}$ \\
\hline Manufacture of rubber and plastic & 0.833 & 0.813 \\
Manuf. of non-metallic mineral products & 0.806 & 0.809 \\
Production of pig iron /ferrous alloys & 0.861 & 0.853 \\
Metallurgy of non-ferrous metals & 0.849 & 0.823 \\
Manufacture of metal products & 0.839 & 0.840 \\
Maintenance, repair and installation of machines & 0.852 & 0.839 \\
\hline Manufacture of other organic and inorganic chemicals & 0.862 & 0.853 \\
Manufacture of pesticides, disinfectants & 0.837 & 0.832 \\
Manufacture of cleaning products, cosmetics & 0.816 & 0.806 \\
Manufacture of machinery & 0.804 & 0.783 \\
Manufacture of cars, trucks and buses & 0.833 & 0.811 \\
Manufacture of parts and accessories & 0.811 & 0.792 \\
Manufacture of other transport equipment & 0.779 & 0.778 \\
\hline Manufacture of pharmaceutical & 0.829 & 0.820 \\
Manufacture of computer, electronic & 0.787 & 0.748 \\
Manufacture of electrical machinery & 0.817 & 0.805 \\
Development of systems and other information services & 0.795 & 0.780 \\
\hline Mean total economy & 0.835 & 0.822 \\
Mean manufacturing & 0.829 & 0.816 \\
Mean nonmanufacturing & 0.841 & 0.829 \\
Mean low technological level & 0.841 & 0.828 \\
Mean medium-low technological level & 0.837 & 0.826 \\
Mean medium technological level & 0.840 & 0.830 \\
Mean medium-high tech. level & 0.820 & 0.808 \\
High technological level & 0.807 & 0.788 \\
\hline Source: & & \\
\hline
\end{tabular}

Source: author's computations.

Note: The software UCINET VI was employed in the estimations.

Both manufacturing and non-manufacturing activities presented substantial efficiency in the spread of information. However, we found a slightly smaller efficiency for manufacturing when compared to the mean of the economy. Statistical tests exhibited that the efficiency for manufacturing and nonmanufacturing showed reduced values, indicating a modest decrease in the diffusion capacity of these segments in 2015. That is, they became less efficient in the spread of knowledge in the productive system. Within the economy, low, mid-low and medium technological activities presented strong diffusion power. These segments concentrated high numbers of structural holes and opportunities to explore its advantages. Some key activities found were: oil refining and coking plants; agriculture; wholesale and retail trade; and manufacture of biofuels. These sectors arguably should be fostered in the short term. The results can serve as a guide for policymakers.

Despite the relevance of the results, the analysis of the numbers offers two possible interpretations. First, given the relevance of some sectors in Brazil, information diffusion is not a valid justification to foster manufacturing. Second, since manufacturing is key in other countries, deindustrialization might have played a role in Brazil, and a solution involves the stimulus of manufacturing activities. Future research must try to fulfill this void. Further- 
more, future studies should investigate the potential to spread information and knowledge in the regions of Brazil. An interregional (and spatial) analysis can contribute to better comprehend the dynamics of the regions. It could complement our analysis at the interregional level.

The results thus suggest a strong but declining capacity of the economy to spread information in the network. A national strategy could focus on sectors in each technological segment with efficiency index superior to the economy's mean. Supporting research in products and processes in the few mid-high activities with diffusion power above the economy's mean, is also relevant to increase the system's capacity to innovate and influence the type of innovations taking place.

\section{References}

Ambrozio, A. M. H. P. \& Melo, L. P. (2017). A nova imagem do setor de serviços. Textos Para Discussão - BNDES, Rio de Janeiro, v. 1, n. 119, p. 1-36, jan.

Aroche Reyes, F. (1995). Cambio tecnico y cambio estructural. La Hipótesis de coeficientes decrescientes. Pruebas estadísticas com datos para México. Estúdios Económicos, v. 10, n. 2, p. 147-162.

Assa, J. (2015). Financial Output as Economic Input: Resolving the Inconsistent Treatment of Financial Services in the National Accounts. Department of Economics. Department of Economics, The New School for Social Research.

Baumol, W. J. (1986). Information Technology and Service Sector: A Feedback Process?. In: FAUHABER, G. (ed.). Services in Transition. The Impact of Information Technology on the Service Sector. 2. ed. Cambridge, Mass: Ballinger Pub. Co.

Borgatti, P. S. (1997). Structural holes: unpacking Burt's redundancy measures. Connections, v. 20, n. 1, p. 35-38.

Borgatti, S. P., Everett, M. G. \& Johnson, J. C. (2013). Analysing Social Networks. Ucinet for windows: software for social network analysis. Sage Publications Ltd.

Burt, R. S. (1988). The stability of American markets. American Journal of Sociology, v. 93, p. 356-395.

Burt, R. S. (1992). Structural holes: the social structure of competititon. Cambridge: Cambridge University Press.

Cassiolato, J. E. \& Vitorino, V. e. (2011). Brics and Development Alternatives: Innovation Systems and Policies. London: Anthem Press, ano. 206 p.

Chang, H. J. (2014). Manufacturing: statements, opening statements and manufacturing: statements, rebuttal statements. The Economist. Disponível em <http://www.economist.com/debate/days/view/714>. Acesso em: 20 mar. 2014.

Cohen, S. \& Zysman, J. (1987). Manufacturing matters: the myth of the postindustrial economy. New York: Basic books. 
Dasgupta, S. \& Singh, A. (2005). Will services be the new engine of Indian economic growth?. Development and Change, v. 36, n. 6, p. 1035-57.

Dietzenbacher, E. \& Luna, R I, B. N. (2005). Using average propagation lengths to identify production chains in the Andalusian economy. Estudios de Economía Aplicada, v. 23, n. 2, p. 405-422.

Galindo Rueda, F. \& Verguer, F. (2016). OECD Taxonomy of Economic Activities Based on R\&D Intensity. OECD Science. Technology and Industry Working Papers, OECD Publishing, Paris, abr.

García Muñiz, A. S., Morillas, A. R. \& Ramos, C. R. (2010). Spanish and European innovation diffusion: a structural hole approach in the input-output field. Annals of Regional Science, n. 44, p. 147-165.

Gonçalves, E. \& Ferreira Neto, A. B. (2016). Intersectoral flows of technological knowledge in emerging countries: an input-output analysis. Revista de la Cepal, n. 118, p. 139-155.

Granovetter, M. S. (1974). Getting a job. Cambridge, Mass.: Harvard University Press.

Hanneman, R. A. \& Riddle, M. (2005). Introduction to social network methods. Riverside, CA: University of California, Riverside (published in digital form at http://faculty.ucr.edu/ hanneman/).

Hidalgo, C. (2015). Why information grows: the evolution of order, from atoms to economies. New York: Basic books.

Hidalgo, C. \& Hausmann, R. (2011). The network structure of economic output. Journal of Economic Growth, v. 16, n. 4, p. 309-342.

Hirschman, A. D. (1959). The Strategy of Economic Development. New Haven: Yale University Press.

Jacinto, A. P. \& Pontual, E. P. (2015). Revista Economia Aplicada, Local, v. 19, n. 3, p. 401-427.

Jackson, M. O. (2008). Social and economic networks. UK: Princeton University Press.

Kaldor, N. (1968). Productivity and growth in manufacturing industry: a reply. Economica, new series, Local, v. 35, n. 140, p. 385-91.

Kon, A. (2003). Atividades Terciárias: induzidas ou indutoras do desenvolvimento econômico? In: FERRAZ, J.C., CROCCO, Marco e ELIAS, L.A. Liberalização econômica e desenvolvimento. Rio de Janeiro: Futura.

Kon, A. (2013). Atividades dos serviçoes como indutoras do desenvolvimento. Revista da Sociedade Brasileira de Economia Politicas, n. 34, p. 57-87.

Lahr, M. L. \& Dietzenbacher, E. e. (2001). Input-output analysis: Frontiers and extensions. Basingstone, UK: Palgrave.

Leontief, W. (1986). Input-Output Economics. New York: Oxford University Press. 
Mansfield, E. (1971). Technological Change. An Introduction to a Vital Area of Modern Economics. New York: W.W. Norton \& Company, Inc.

Mazzucatto, M. (2014). The Entrepreneurial State: debunking public vs. private sector myths. London and New York: Anthem Press.

Miller, R. E. \& Blair, P. D. (2009). Input-output Analysis: Foundations and Extensions. New York: Cambridge University Press.

Mohnem, P. (2001). International R\&D Spillovers and Economic Growth. In: M. Pohjola (Ed.). Information Technology, Productivity, and Economic Growth: International Evidence and Implications for Economic Development. Oxford: Oxford University Press, p. 55-71.

Ocampo, J. A., Rada, C. \& Taylor, L. (2009). Growth and policy in developing countries: a structuralist approach. New York: Columbia University Press, 178 p.

OECD - Organização para a Cooperação e Desenvolvimento Econômico (2003). OECD Science, Technology and Industry Scoreboard 2003. OECD Publishing. DOI: 10.1787/sti_scoreboard-2003-en.

OECD - Organização para a Cooperação e Desenvolvimento Econômico (2011). ISIC Rev. 3 technology intensity definition. OECD Directorate for Science, Technology and Industry, jul.

Rodrik, D. (2010). Políticas de diversificação econômica. Revista CEPAL, Número especial.

Rosenberg, N. (1982). Inside the Black Box: Technology and Economics. Cambridge: Cambridge University Press.

Scherer, F. (1982). Interindustry technology flows and productivity growth. Review of Economics and Statistics, n. 64, p. 627-34.

Schmookler, J. (1966). Invention and Economic Growth. Cambridge, Massachusetts: Harvard University Press.

Schumpeter, J. (1994). Capitalism, socialism and democracy. Harper and Brothers, New York.

Shaik, A. M. \& Tonak, E. A. (1994). Measuring the wealth of nations: the political economy of national accounts. Cambridge, UK: Cambridge University Press, $380 \mathrm{p}$.

Souza, N. J. (1988). Agricultura e integração industrial no Brasil. Revista Ensaios FEE, v. 9, n. 2, p. 46-63.

Syrquin, M. (1988). Patterns of structural change. In: H. Chenery and T. Srinivasan (eds). Handbook of development economics. London: Elsevier.

VieiraFilho, J. E. R., Santos, G. R. \& Fornazier, A. (2013). Distribuição produtiva e tecnológica da agricultura brasileira e sua heterogeneidade estrutural. CEPAL-IPEA, Brasilia, n. 54. (Textos para Discussão).

Wolff, E. N. (1997). Spillovers, linkages and technical change. Economic Systems Research, v. 9, n. 1, p. 9-23. 


\section{Appendix A}

The 62 sectors present in the matrices are: Agriculture (1), Livestocks (2), Forestry and fisheries (3), Extraction of coal and non-metallic minerals (4), Extraction of oil and gas, including support activities (5), Extraction of iron ore, including processing and agglomeration (6), Extraction of non-ferrous metal ores (7), Slaughter and meat products, including dairy products and fishery products (8), Manufacture and refining of sugar (9), Other Food Products (10), Manufacture of beverages (11), Manufacture of tobacco products (12), Manufacture of textiles (13), Manufacture of wearing apparel and accessories (14), Manufacture of footwear and leather goods (15), Manufacture of wood products (16), Manufacture of pulp, paper and paper products (17), Printing and reproduction of recordings (18), Oil refining and coking plants (19), Manufacture of biofuels (20), Manufacture of other organic and inorganic chemicals, resins and elastomers (21), Manufacture of pesticides, disinfectants, paints and various chemicals (22), Manufacture of cleaning products, cosmetics / perfumes and toilet preparations (23), Manufacture of pharmaceutical and pharmacokinetic products (24), Manufacture of rubber and plastic products (25), Manufacture of non-metallic mineral products (26), Production of pig iron / ferrous alloys, steel and seamless steel tubes (27), Metallurgy of nonferrous metals and metal smelting (28), Manufacture of metal products, except machinery and equipment (29), Manufacture of computer, electronic and optical products (30), Manufacture of electrical machinery and equipment (31), Manufacture of machinery and mechanical equipment (32), Manufacture of cars, trucks and buses, except parts (33), Manufacture of parts and accessories for motor vehicles (34), Manufacture of other transport equipment, except motor vehicles (35), Manufacture of furniture and products of various industries (36), Maintenance, repair and installation of machinery and equipment (37), Electricity, natural gas and other utilities (38), Water, sewage and waste management (39), Construction (40), Wholesale and retail trade, except motor vehicles (41), Ground transportation (42), Maritime transportation (43), Air transport (44), Storage, auxiliary transport and mail activities (45), Accommodation (46), Food supply (feeding) (47), Print-integrated editing and editing (48), Television, radio, cinema and sound / image recording / editing activities (49), Telecommunications (50), Development of systems and other information services (51), Financial intermediation, insurance and supplementary pension plans (52), Legal, accounting, consulting and corporate headquarters activities (53), Architectural, engineering, testing / technical analysis and R \& D services (54), Other professional, scientific and technical activities (55), Non-Real Estate Rentals and Intellectual Property Asset Management (56), Other administrative activities and complementary services (57), Surveillance, security and research activities (58), Private education (59), Private health (60), Artistic, creative and entertainment activities (61) and Associations and other personal services (62).

\section{Appendix B : Burt's original method}

Burt (1992) measures the indicator of non-redundancy as follows. Herein notation and model's exposition are drawn from García Muñiz et al. (2010). Firstly, it is necessary to measure the redundancy level. If we evaluate the number of redundant contacts of a sector " $\mathrm{i}$ " with other sectors like " $\mathrm{q}$ " and 
" $\mathrm{j}$ ", it is possible to compare them and find out which one is redundant. The information accessed through a relation with " $j$ " is redundant since " $i$ " spent time (and investment) to maintain a relationship with " $\mathrm{q}$ " while the latter is connected to "j". Figure B.1 exhibits this relationship.

Figure B.1: Example of redundant linkages of sector "i".

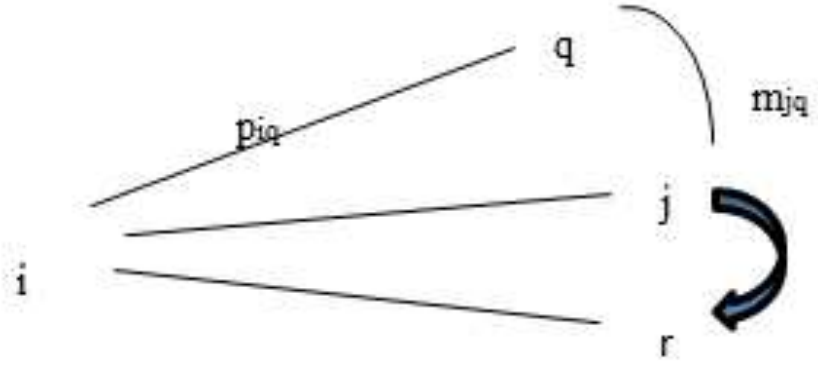

Source: author's elaboration, adjusted from Burt (1992). Note: $r$ stands for a given sector in the network.

The redundancy, $R_{i(j)}$, of the connections exhibited in Figure B.1 can be expressed mathematically as:

$$
R_{i(j)}=\sum_{q} p_{i q} m_{j q} ; q \neq i, j
$$

in which subindex $q$ denotes the additional activities connected to both activities $\mathrm{i}$ and $\mathrm{j}, p_{i q}$ represents the energy spent in the relation with " $\mathrm{q}$ ". That is, $p_{i q}$ indicates the sector's i direct productive connections as a proportion, captured by the intermediate flows $x_{i q}$ and $x_{q i}$. It can be written as:

$$
p_{i q}=\frac{\left(x_{i q}+x_{q i}\right)}{\sum_{j=1}^{n}\left(x_{i j}+x_{j i}\right)}, i \neq j
$$

Where, as aforementioned, $\mathrm{x}$ stands for the interflow of sectoral transactions. The second term of Equation 1 represents the marginal strength of the links between sectors " $\mathrm{j}$ " and "q". That is the relevance of the contact between " $\mathrm{j}$ " and " $\mathrm{q}$ " weighted by the most crucial link that sector " $\mathrm{j}$ " retains. It exhibits the contact redundancy level. For more details, see Burt (1992) and García Muñiz et al. (2010).

$$
m_{j q}=\frac{\left(x_{j q}+x_{q j}\right)}{\max _{k}\left(x_{j k}+x_{k j}\right)} ; j \neq k
$$

Having estimated the redundancy level, $R_{i(j)}$, the level of non-redundancy (TEi) can be computed as a residual. The level of non-redundancy is equal to the network size of sector " $\mathrm{i}$ ", $N_{i}$ minus its level of redundancy $\left(T E_{i}=N_{i}-\right.$ $\left.\sum_{j} R_{i(j)}\right)$. The smaller this indicator, the less access to information this sector 
holds. This indicator is known as effective size and provides the number of non-redundant links. It shows the maximum variety of information resources that a given sector detains.

The previous measure (TEi) can be normalized by network size, $N_{i}$, for the consistent comparison between structures. This indicator is called efficiency index $\left(E_{i}=\frac{T E_{i}}{N_{i}}\right)$. This index reveals which proportion of ego's linkages to its ego network is non-redundant (Hanneman \& Riddle 2005). It exhibits values between 0 and 1 . Values near 1 highlight a high number of non-redundant productive links giving varied information. 